\title{
Refundar a educación para refundar a esquerda
}

Se queremos refundar a esquerda, teremos que comezar seguramente por refundar a educación. Debemos comezar pola base para cambiar esa base. Se queremos unha esquerda nova, plural e concreta haberá que traballar por unha educación nova que nos una, que nos concite, que nos estimule, que nos agrupe, que nos ilusione. Unha educación de nación para que Galicia sexa "dona de si e señora de se afirmar ou de se negar", como tan expresivamente ten dito Uxío Novoneyra nese canto á autodeterminación que son os seus "alalás encadeados".

Precisamos, en fin, unha nova educación que sexa moi creativamente política, moi crítica, moi innovadora, moi rupturista. Visto que o capitalismo non para de xerar desigualdades e inxustizas. Visto que o capitalismo xa está instalado no roubo, na estafa e na explotación máis depredadora, precisamos urxentemente unha alternativa rigorosamente anticapitalista. A esquerda, a nova esquerda non pode ficar estancada. Terá que inventar. Deberá inventar. Haberá que ir ao corazón mesmo dos problemas. Teremos que perder o medo a errar. Teremos que reescribir todo o que deba ser reescrito. Teremos que reformular todo o que deba ser reformulado.

Nun texto moi breve de 1869, presentado diante do Consello Xeral da Asociación Internacional do Traballo de Xenebra, Carlos Marx, falando sobre temas de educación e ensino, dicía: "Unha dificultade moi peculiar está ligada a esta cuestión. Por unha parte, é necesario cambiar as condicións sociais para crear un novo sistema de ensino; por outra, precisamos un sistema de ensino novo para poder cambiar as condicións sociais. En consecuencia, é necesario partir da situación actual".

Así de sinxelo. Así de simple. Nin ten volta nin nos podemos queixar... Porque non podemos escoller as condicións en que queremos facer a historia. Temos que partir do que hai. Temos que cambiar o que hai a partir do que hai. Debemos partir da realidade concreta e axustarnos a ela. Pero sabendo que esa realidade, cando está podre, deberá ser cambiada. A vida nace na podremia, dicía tamén Marx. Teremos pois que actuar sempre criticamente, radicalmente, revolucionariamente. Porque xa está visto que as reformas, sen máis, non solucionan os problemas. O reformismo está sendo arrastrado cada día polo vendaval neoliberal. Estámolo a ver.

E como tamén dicía Marx —outra vez Marx, sempre Marx - "a teoría materialista do cambio das circunstancias e da educación esquece que as circunstancias son as persoas as que as fan cambiar e que o educador tamén necesita ser educado". Polo tanto, deberemos volver ás raíces ilustradas da educación e da cultura. Non nos queda outra. Por iso, a educación e a cultura non só deben ser alicerces para a toma de conciencia política e moral, senón que deberán ser armas ao servizo do cambio político e da revolución.

(Texto escrito en maio de 2010 e lido no acto "Refundar a esquerda", celebrado en Santiago de Compostela.) 